\title{
Major Red Beans Marketing Channels in Halaba Special District, Ethiopia
}

\author{
Agete Jerena Kabeto \\ Ethiopian Biodiversity Institute, Hawassa Biodiversity Center, Ethiopia
}

*Corresponding Author: Agete Jerena Kabeto, Ethiopian Biodiversity Institute, Hawassa Biodiversity Center, Ethiopia

\begin{abstract}
Exploring available marketing channel and selecting the best rewarding among is as important as production decision. This study attempted to explore available marketing channels and constraints associated with red beans producers and traders in the study area. In Halaba Special District (HSD) production of red beans got attention from both farmers and government side but available market channels and associated margin were not explored. This study aims to identify the available red beans market channel and explore associated margins through field survey and Focus group discussion (FGD). The survey was conducting through field interviews based on a questionnaire that was designed for both red beans farmers and traders. The questionnaire was pre-tested and a sample of 150 red beans farmers and 33 red beans traders were selected at random. Both descriptive statistics and qualitative analysis for (FGD) were used. There were seven major red beans market channels in HSD. In terms of quantity of red beans handled only two market channels seemed important, i.e., urban collectors and wholesalers who handled 79 and 19 percent respectively. Results indicated that red beans farmers obtain highest market profit (2.2) in channel II when they sold their produce directly to wholesalers and producer market share (65.16) was highest in this channel as well. Furthermore, significant difference were observed between red beans farmers who sold their output and those who did not sell their red beans with regard land allocation, quantity produced, quantity of red beans consumed, and post harvest losses of red beans. Research results indicated that, there is need to bring policy that supports red beans farmers to sell their produce directly to wholesalers and hence, increase their margins.
\end{abstract}

Keywords: Market channel, Market actors, Marketing margin

\section{INTRODUCTION}

Ethiopia is among the top pulse producing countries in the world. Pulse occupies 11 percent of the total grain production of the country and second most important in the national diet next to cereals. The crop occupies the third position in Ethiopian export earnings next to coffee and oil crops (Mulugeta, 2010). Production volume of pulse crop is increasing in the country while only 13 percent of the total produces joining market in the presence of increasing demands both at local and international markets (ibid). In Ethiopia common beans (red and white) production is increasing due to its increased domestic and international demands. In the country common beans solely produced by smallholder farmers and the production was increased from 138 thousand tons to 463 thousand tons in 2012. The country earned 19 million USD and 95.3million USD in 2005 and 2012 respectively from common beans export market. In the country the value chain of beans remains underdeveloped and hence smallholder farmers and traders earn a low share from the commodity (FAO, 2015).

According to (Bisschop and Dijk, 2007) research report, red beans are principal food crop particularly in southern nations nationality and people region (SNNPR) of Ethiopia. The country red beans has high demand in Africa, Arabia, Asia, and some EU countries, and it is exported to different part of the world (Bindera, 2009). The increasing demand for quality red beans on the world export market is a great opportunity for Ethiopian red beans farmers to boost their income from red beans if they are linked to well-organized marketing channel. In very rare cases farmers sell their output to consumers and it is common for a given product to pass in a series of marketing channels and these channels will involve several intermediaries. 
It is argued that linking farmers to output market through efficient value chains would increase farmers' market participation and their income (Kumar and Kapoor, 2010). This implies that agricultural production coupled with good market linkage would ignite agricultural development indicating marketing plays a vital role in agricultural development (Narayanan and Bastine, 2004). Identifying the most efficient marketing channel with higher marketing margin is, thus, critical to optimize the marketing costs and to ensure remunerative prices to the producers (ibid). Furthermore, marketing channel selection is as important as production decision to actualize expected development goals (LeRoux, 2010).

In SNNPR, Halaba Special District is one of the largest red beans producing district. In recent years, red beans production and land allocation have been increasing in the district. The average land area covered by red beans was 19,262 hectares between 2008 and 2011 and in the district; area coverage was not more than 10,000 hectares before 2008. The average red beans production increased from 28,000 MT in 2008 to 40,000 MT in 2011 (HSDMD, 2012). Though red beans production and its demands are increasing, major marketing channels and constraints of farmers and traders were not explored in the district.

\section{MeThodologY}

\subsection{Study Area}

Halaba Special District is located in Southern Nation Nationality People Region (SNNPR), located at $315 \mathrm{~km}$ from Addis Ababa and $90 \mathrm{~km}$ from regional capital, Hawasa, on the main road to Arbaminch. The district has 79 rural Kebele Administrative (KA) and five urban KA, and Kulito is the capital. The district is called "special" because it has a special status where the administration directly reports to the regional state. The latitude and longitude of study area is $7^{\circ} 19^{\prime} 12^{\prime \prime} \mathrm{N}$ and $38^{\circ} 4{ }^{\prime} 47^{\prime \prime} \mathrm{E}$ respectively. The District is located East of Kembata Tembaro zone, west of Oromia region, North, and South-East of Hadiya zone and South-East of Silte zone.

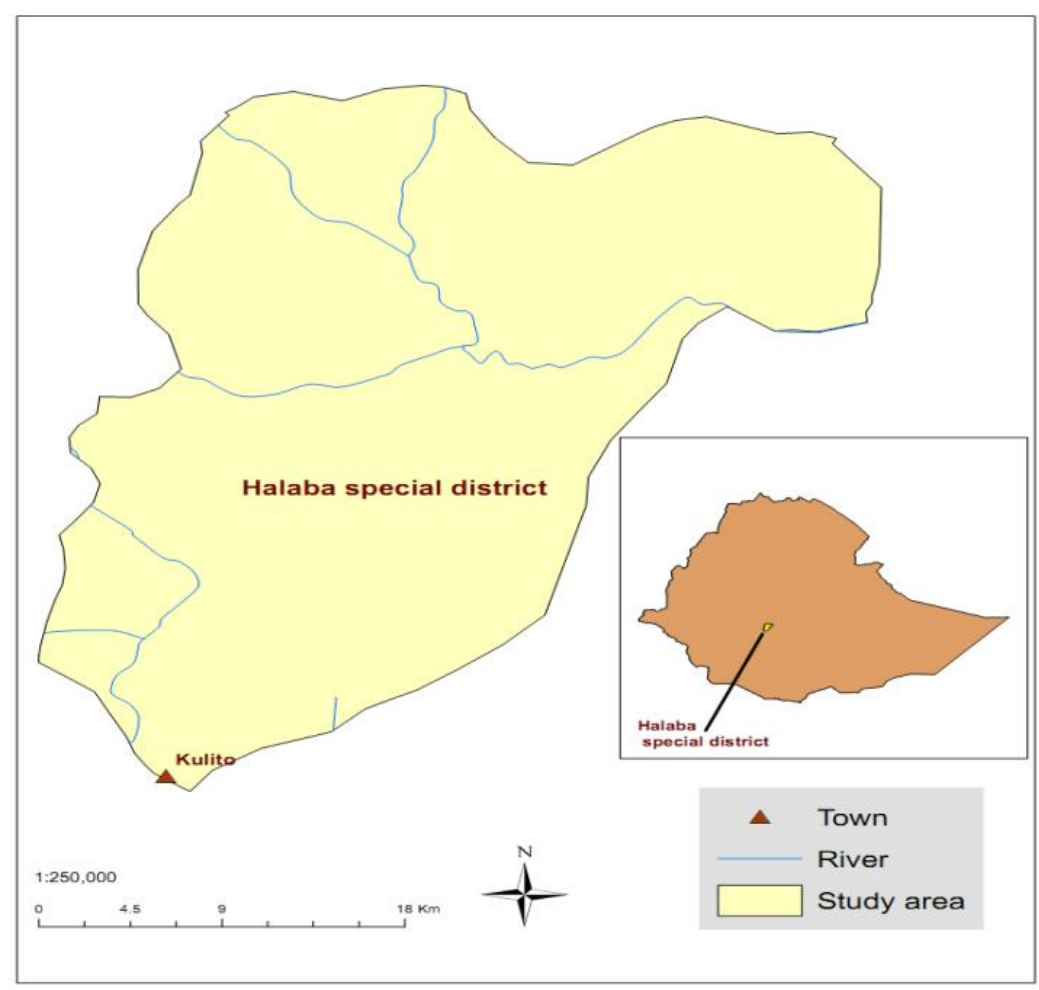

Fig1: Map of Halaba Special District

Source: ILRI GIS (2012)

\subsection{Sampling Technique}

A multi-stage sampling procedure was employed in order to draw a sample from red beans producers. First, the district was selected purposively because of red beans production potential and scanty 
information on marketing channels in the district. Secondly, red beans producing KA (kebele administration) were identified based on information from agriculture and rural development office. Out of $79 \mathrm{KA}$ in district, $45 \mathrm{KA}$ were dominant red beans producers. Thirdly, five KA and four villages were randomly selected from each of the five KA. Proportions to size were calculated to decide on the number of samples from each KA. Based on the proportions done, random number table were used to come up with samples 150 red beans farmers. In order to get the sample of traders, stratified sampling was employed. First, the traders were grouped into homogenous categories, i.e., different types of traders like rural assemblers, urban collectors, cooperatives, and cooperative union. Then 33 respondents were selected randomly from the groups of traders.

\subsection{Data Sources}

Primary data were used for this study. The data were collected from a sample of 150 red beans farmers and 33 local traders (12 urban collectors, 12 rural assemblers, 4 wholesalers, 4 primary cooperatives, 1 cooperative union) using a semi-structured and pre-tested questionnaire in the year 2012. The informal interview comprised two focus group discussions (FGDs) and key informant interviews with producers, urban collectors, rural assemblers, wholesalers, elders of the community, female representatives of KA (kebele administration), chairperson of KA and development agents to generate more information on the market chain.

\subsection{Data Analysis}

The questionnaire data were captured in SPSS Version 16 computer packages and analyses were undertaken. The data from FGD and key informant interviews were analyzed qualitatively and used in the text to boost the information from quantitative analysis.

\subsection{Marketing Channels}

Market channel involve a group of people or organizations that direct the flow of agricultural commodities from producers to consumers. It includes all market levels and actors that have a role in the distribution of a given commodity from farmer to consumer. Out of the total 150 farmers sampled for this study, only those farmers who sold their red beans in the year 2012 were used to develop marketing channels.

\subsection{Marketing Margins}

Marketing margin is the difference between the value of a product or group of products at one stage in the marketing process and the value of an equivalent product or group of products at another stage (Smith, 1992). It measures the share of the final selling price that is captured by a particular agent in the marketing chain (Mendoza, 1995). The total gross marketing margin (TGMM) is the difference between price per unit of that product at the farm gate and the price per unit when sold to the final consumer (Smith, 1992).

$$
\mathrm{TGMM}=\frac{\text { End buyer price }- \text { First seller price }}{\text { End buyer price }} * 100--------------(1)
$$

In order to gauge the level of equity in the distribution of benefits accrued along the value chain, producer's gross margin (GMMP) which is the portion of the price paid by the end buyer that goes to the producer was calculated as:

$$
\text { GMMP }=\frac{\text { End buyer price }- \text { marketing gross margin }}{\text { End buyer price }} * 100------------(2)
$$

Because precise marketing costs are frequently difficult to determine in many agricultural marketing chains in developing countries due to price data limitations, the gross rather than the net marketing margin is calculated. Thus, the marketing margin in this study was understood as gross marketing margin (Scott, 1995).

\section{RESULTS AND DISCUSSION}

Among the respondent in HSD about 19 percent were female headed households while 81 percent were male headed households. The mean age of red beans producers was 41 years and the average 
years of formal education were 2 years. In the district, the average number of family members for red beans farmers was seven. The mean farming experience of red beans farmers was 22 years and the total land size owned was 1.7 ha from which 0.5 ha was allocated for red beans production. Results of the survey revealed that 56 percent of the farmers were red beans market participants while 44 percents of the producers were not participated on the red beans market. The mean age, education level and trading experience of urban collectors were 40.3, 5.8 and 4.2 respectively. Similarly, the mean age, education level and trading experience of rural assemblers were 38.2, 4.9 and 5.2 respectively. Furthermore, the mean age, education level and trading experience of wholesalers were 49,6 and 13.5 respectively in the study area.

\subsection{The Red Beans Market Channels in HSD}

The flow of red beans from farmers to different marketing channels is presented in Figure 2 below. Out of 150 farmers 85 farmers were sold their red beans to different marketing channels and the market channel was developed based on these farmers. There were seven major red beans marketing channels in the study area. In terms of quantity of red beans bought directly from farmers, only two marketing channels seemed important, i.e., urban collectors and wholesalers who bought 79 percent and 19.5 percent respectively. The remaining balance was directly sold to primary cooperative and rural assemblers. The most patronize outlets were the urban collectors who bought 79 percent of the produce directly from farmers; this could be due to the fact that farmers can easily access urban collectors in the market places, whereas wholesalers handle the first position in channeling large amount of red beans outside the district. This could be wholesalers have license that allow them to channel the red beans to other markets outside the district. This finding corroborates that of Mussema and Dawit (2012) who found that in Alaba Special District wholesalers were the major outlet of red pepper to other markets.

On figure 2, the arrow from NGOs back to farmers shows the flow of red beans from NGOs to farmers in the form of aids. In the year preceding the survey, NGOs bought red beans from cooperative union (Mancheno) and distributed it to farmers as planting materials to enhance household food security. In the district, cooperative union, urban collectors and rural assemblers channeled all what they bought to wholesalers with little exception to cooperative union and few rural assemblers.

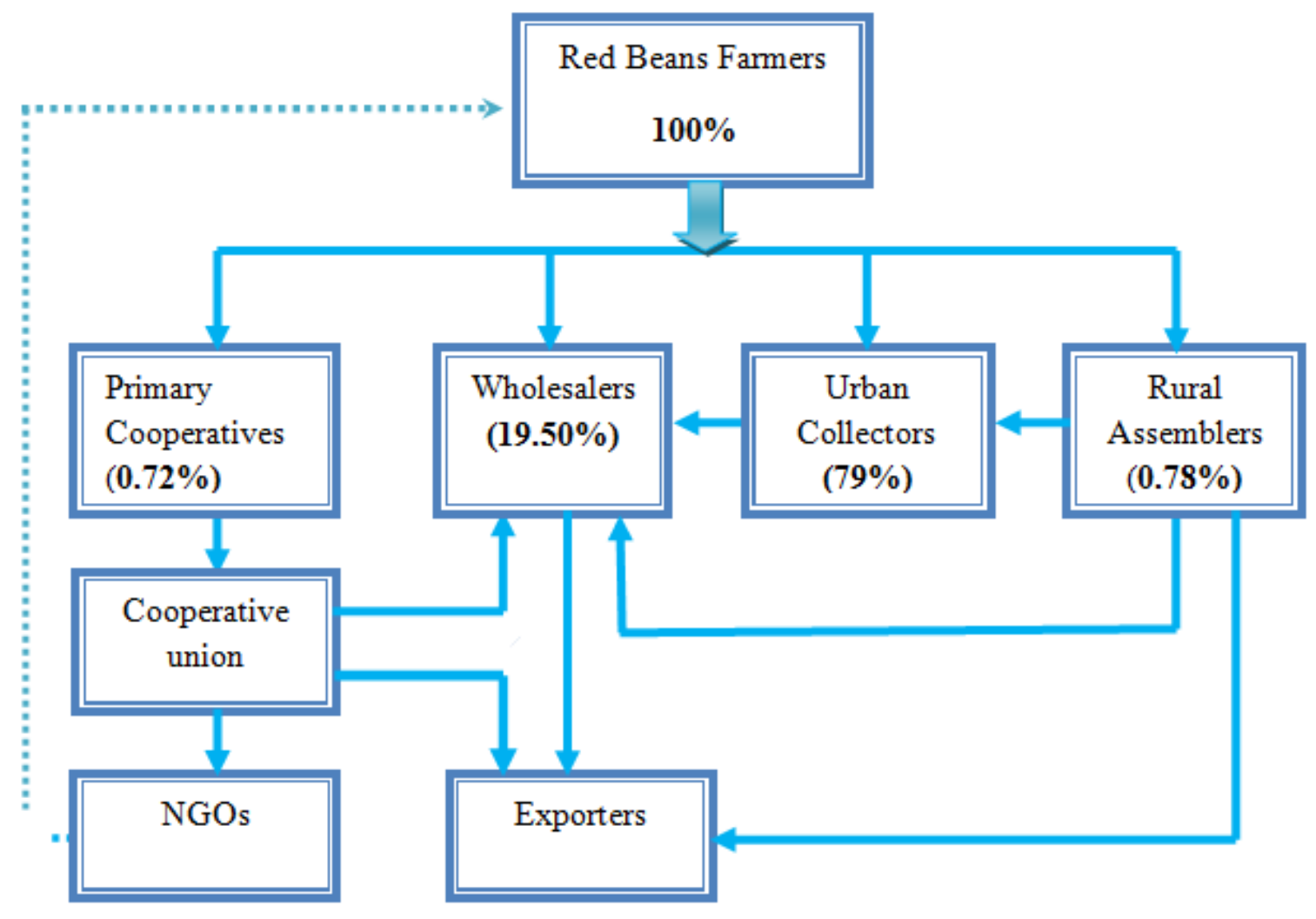




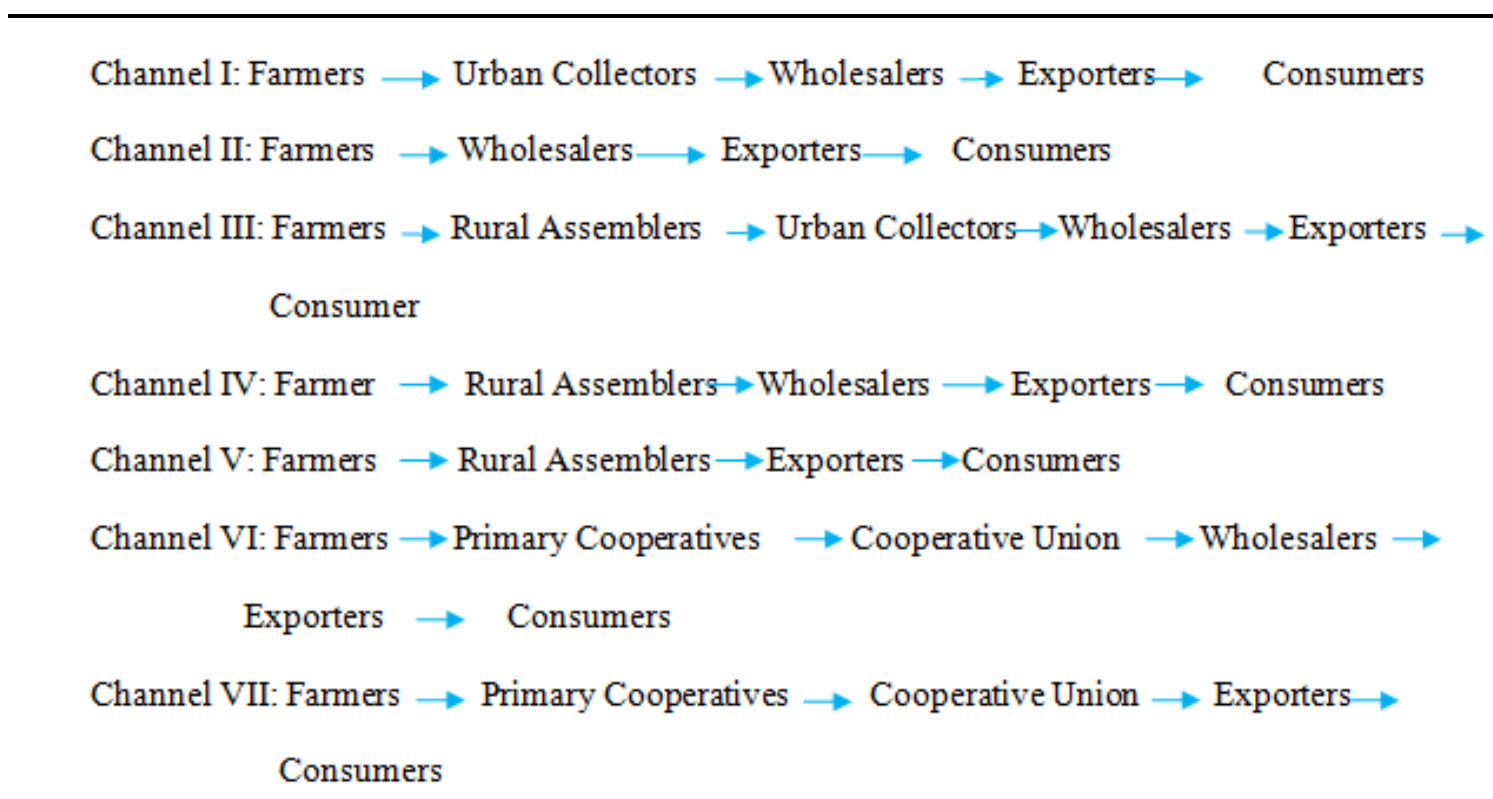

\section{Major Market ACtors And Their Role in Red Beans Marketing Chain}

\subsection{Producers}

This study considered producers as the first step in the market chain. Red beans producers harvest and consume some at home, give some as gift, some preserved as planting material for next season, some lost due to post harvest problem and supply the rest to the traders in the market. Table 1 compares red beans market participants and non-participants with regard to red beans farmers land allocation, Production, consumption, post-harvest losses, and quantity of red beans offered as gift in HSD in the year 2012.

Table1: Red beans farmers land allocation, production, consumption, post harvest loss and gift given to others in $H S D$

\begin{tabular}{|l|l|l|l|l|l|l|}
\hline \multirow{2}{*}{ Item } & \multicolumn{3}{l|}{$\begin{array}{l}\text { Red beans market } \\
\text { Participants }\end{array}$} & \multicolumn{2}{l|}{$\begin{array}{l}\text { Red beans non- } \\
\text { market } \\
\text { participants }\end{array}$} & \\
\cline { 2 - 7 } & & & Mean & n & Mean & P-value \\
\hline Land allocated for red beans in 2012 (ha) & 85 & $0.6(0.4)$ & 65 & $0.4(0.3)$ & $0.019^{* *}$ \\
\hline Quantity of red beans produced in 2012 $(\mathrm{Kg})$ & 85 & $430.6(346.7)$ & 65 & $161.2(92.5)$ & $0.005^{* * *}$ \\
\hline Quantity of red beans consumed in 2012 & 73 & $103.1(85.7)$ & 62 & $137.5(80.1)$ & 0.891 \\
\hline Quantity of red beans preserved for seed & 49 & $47.1(36.5)$ & 30 & $21.0(14.2)$ & $0.009^{* * *}$ \\
\hline Quantity of red beans lost due to post harvest losses & 43 & $26.9(18.1)$ & 18 & 22.1 & $(17.2)$ & 0.768 \\
\hline Quantity of red beans used as gift & 37 & $29.6(23.6)$ & 18 & 22.1 & $(15.9)$ & 0.169 \\
\hline
\end{tabular}

Source: Survey data (2012: The numbers in parenthesis indicate standard deviation. $* * *, * *, *=$ significant at 1,5 and 10 percent respectively

In HSD almost all red beans farmers have their own farm land. The average land size under red beans production was 0.6 and 0.4 ha per household among market participants and non-participants respectively. The result implies that the size of land allocated is less than one hectare indicating small land size allocation for the crop. This result is in line with the findings of (Ferris and Kaganzi, 2008) who found with high population pressure, farm sizes are small and 56 percent of farming households farm less than one hectare in the study area. The average land size was significantly different between the groups $(\mathrm{p}=0.019)$ indicating that market participants of red beans had larger farm size than nonmarket participants. This indicated that in HSD, the size of land allocated for red beans production was among reasons for farmers' market participation.

Results on Table 1 above showed that, on average every red beans market participants produced about $430 \mathrm{~kg}$ while non-market participants produced about $161 \mathrm{~kg}$ of red beans in the year preceding the survey. From this average production, $303 \mathrm{~kg}$ (70 percent) was sold to different traders. The average quantity of red beans consumed by red beans market participants and non-participants was $103 \mathrm{~kg}$ and $138 \mathrm{~kg}$ respectively. These amounts were not statistically different between market participants and non-participants $(\mathrm{p}=0.891)$. Red beans market participants used more land for red beans in 
comparison to their counterparts but consumed less (Table 1). Higher land allocation that resulted in higher production coupled with low consumption might help market participants to participate in the market. The quantity of red beans preserved for seed, the post harvest loss and the quantity given as gift by market participants and non-market participants was not significantly different $(\mathrm{P}=0.169)$.

\subsection{Brokers}

Brokers are agents who work for a commission on behalf of other participants (Mussema, 2006). According to farmers report, red beans farmers were unable to determine the price of their produce because there are too many brokers confusing farmers along the value chain. Brokers specialized in bringing the buyers and sellers together but most of the time they allegedly cheated farmers; almost all farmers complained about brokers during the FGDs. Ketema (2007) also reported that in Ethiopia, brokers are the ones who decide on the price of goat and sheep markets and cheated farmers in Alaba Special District. These intermediaries played important roles in collecting red beans for wholesalers, and they got their reward on the basis of the quantity they had bought. Wholesalers and rural assemblers gave money to their brokers in the morning of every market day and brokers are responsible to buy and transport the produce to the store in the same day in the afternoon or the morning of the next day. There was no formal contractual agreement but oral agreement would be made between traders and brokers.

\subsection{Urban Collectors}

The urban collectors play important role in the red beans collecting system which accounted 79 percent in the year 2012 and reselling back to district wholesalers. They bought red beans directly from farmers and rural assemblers. Urban collectors did not have any contractual agreements with farmers as well as other traders as it was reported during the FGDs. They purchased red beans directly from farmers and did not involve brokers. These traders did not grade red beans but they clean it rarely. Urban collectors mainly used pack animals and animal cart for transportation of red beans from market to store and vice-versa. These traders reported that they did not keep red beans trade data mainly due to lack of knowledge on importance of trade record keeping. This could be improved through training. The costs incurred by urban collectors were cost of cleaning, transportation and storage. The total gross margin was 16.3 and 7.1 percent in channel I and III respectively (Table 3). Among the traders the least margin was received by urban collectors which could be related to little value addition by urban collectors.

Table 2 below indicates different types of marketing costs related to the transaction of red beans by urban collectors, rural assemblers, wholesalers, primary cooperatives, and cooperative union.

Table2: Selling price and marketing costs of red beans actors in HSD

\begin{tabular}{|c|c|c|c|c|c|c|c|c|}
\hline Actor & Prices, cost and profit & Ch-I & Ch-II & Ch-III & Ch-IV & Ch-V & Ch-VI & Ch-VII \\
\hline Farmers & Selling price (ETB/kg) & 4.9 & 5.05 & 4.1 & 4.1 & 4.1 & 4.3 & \\
\hline & Marketing cost & - & - & - & - & - & - & - \\
\hline $\begin{array}{c}\text { Primary } \\
\text { Coop. }\end{array}$ & Selling price (ETB/kg) & & & & & 5.83 & 5.83 & 5.83 \\
\hline & Marketing cost & & & & & 0.6 & 0.6 & 0.6 \\
\hline $\begin{array}{c}\text { Coop. } \\
\text { Union }\end{array}$ & Marketing profit & & & & & 0.6 & 0.6 & 0.6 \\
\hline & Selling price (ETB/kg) & & & & & 7.9 & 7.9 & 7.9 \\
\hline $\begin{array}{c}\text { Rural } \\
\text { Assembleting cost }\end{array}$ & Marketing profit & & & & & 1.1 & 1.1 & 1.1 \\
\hline & Selling price (ETB/kg) & & & 5.4 & 5.8 & 7.2 & & 1.3 \\
\hline & Marketing cost & & & 0.7 & 0.7 & 1.5 & & 1.3 \\
\hline $\begin{array}{c}\text { Urban } \\
\text { Collectors }\end{array}$ & Selling price (ETB/kg) & 6.2 & - & 6.2 & & & & \\
\hline & Marketing cost & 0.3 & - & 0.2 & & & & \\
\hline Mholesalers & Melling price (ETB/kg) & 7.75 & 7.75 & 7.75 & 7.75 & - & 7.75 & \\
\hline & Marketing cost & 1.1 & 1.1 & 1.1 & 1.1 & - & 0.3 & \\
\hline & Marketing profit & 1.6 & 2.2 & 1.6 & 1.9 & - & 0.7 & \\
\hline
\end{tabular}

Source: Survey data (2012); Ch-represents channel 


\subsection{Primary Cooperatives Society}

There were 40 primary cooperatives in HSD during the survey period. Of these, eight participated in red beans marketing and four of them were interviewed for this research work. The four cooperatives interviewed were Nape Keno, Amelamo Grain Trading Service, Metoma Grain Trading, and Upper Bedenea Cooperative Society. These cooperatives were mainly trading with teff, maize, and red beans. Among the primary cooperatives, Nape Keno participated in improved red beans seed production, and sold the seed to the cooperative union that solicited for markets. None of them bought red beans contaminated with soil or stones and with shriveled grains as these would compromise the quality demanded by the cooperative union. During the FGDs, most of the farmers reported that they did not prefer selling their produce to cooperatives because of quality restrictions and this could be solved through training farmers on red beans post harvest handling to improve quality.

There was contractual agreement between the cooperative societies and the cooperative union such that the former were expected to supply quality red beans and cooperative union is responsible to buy the red beans supplied by cooperative. There was no contractual agreement between the primary cooperatives and farmers; farmers who are members of the cooperative were free to sell their produce anywhere they wished at any price. In the district, the cooperative union was given the assignment of working with primary cooperatives in searching for markets, and bargaining with other traders, and supplied to deficit markets outside the district. The government gave this assignment to the cooperative union because they had better market information and bargaining power (HSDMD, 2012).

The cooperatives used both animal carts and trucks for transporting red beans, the former for short distances while the latter for relatively longer stretches. All the cooperatives stored what they bought and sold it latter to the cooperative union at an average price of ETB 5.83/kg for the commodity that they bought for $4.3 \mathrm{ETB} / \mathrm{kg}$ (Table 2). The total gross margin for primary cooperatives was 21.3 percent in channel VI and VII (Table 3).

\subsection{Cooperative Union}

There was one cooperative union in the district called Mancheno that cooperatives societies were affiliated to. The cooperative union was established in Kulito town in 2004 with eight cooperative society members, although it started buying red beans from the cooperative societies in 2008. The union bought the produce from cooperative societies working in rural areas where there was production. The union trades in maize, wheat, teff, red beans, red pepper, white beans, and millets. The union participated in the market by buying red beans through cooperative societies, and reduced price volatility of different commodities in the district. The cooperative union considered red beans variety, color and size of the grain as major quality attributes and the inspection was done by only visual observation. The variety traded by the union was called Nasir. The major means of transportation was trucks. It supplied NGO, and other traders within and outside the district. The term of payment with both suppliers of the union and buyers of the union was in cash. The costs incurred by the cooperative union were transportation, loading and unloading, cleaning, sorting, packaging, rent for store and grading. They bought for $5.5 \mathrm{ETB} / \mathrm{kg}$ and sold $7.9 \mathrm{ETB} / \mathrm{kg}$ (Table 2). Total gross margin for cooperative union was 20.5 percent of end buyer's price in channel VI and channel VII (Table 3).

\subsection{Rural Assemblers}

Rural assemblers mainly bought small lots of red beans directly from farmers in rural markets and roadsides and finally sold to wholesalers, urban collectors, and exporters, depending on best price offered Fig 2. According to FGDs, rural assemblers added value, such as intensive cleaning, fumigating, sorting and grading and store for some time until they got reasonable price in the market. In the district, the entire rural assemblers did not get any credit from banks but obtained credit from friends and relatives. The main sources of information on price of red beans were urban collectors, wholesalers, and exporters. They used their own financial resources to buy red beans and their indigenous knowledge to bulk red beans. The rural assemblers used animal carts to collect red beans from the village and also trucks (especially when selling to exporters). There was no contractual agreement between rural assemblers and farmers and other buyers. The additional costs for rural assemblers were transportation, loading, and unloading. 
Majority of rural assemblers bought red beans directly from farmers and this is because rural assemblers are traders who live next to the farmer and buy directly from the farmer. Aysheshm (2007) reported that in Ethiopia, along sesame value chain rural assemblers buy small lots of sesame directly from farmers and sold to wholesalers and exporters. They paid ETB 4.1/kg and received ETB 5.4, 5.8 and $7.2 / \mathrm{kg}$ when they sold to urban collectors, wholesalers and exporters respectively (Table 2). The total gross margin for rural assemblers was $24.3,29.7$, and 43.3 percent of end buyer's price in channel III, IV and V respectively (Table 3 ).

\subsection{Wholesalers}

Wholesalers are traders who buy large quantities of red beans and resell to other traders both in local and export markets. With regard to quantity handled and channeled to outside the district, wholesalers were the major actors, and channeled the produce to exporters and other wholesalers. Wholesalers who were interviewed responded that they had their own brokers who could buy red beans on their behalf. This could be because wholesalers dealt with huge amount of red beans that could not be collected by only the wholesalers. Aysheshm (2007) found that in Ethiopia along sesame market chain wholesalers used brokers and commission agents to collect sesame grain. Jagwe (2011) reported that wholesalers of banana in Rwanda, Burundi and Democratic Republic of Congo handle the largest volume of banana and have intermediaries who can collect banana from different sources.

Wholesalers graded the produce based on color and size. Commonly, wholesalers used trucks for transportation of red beans. Wholesalers bought red beans from farmers, urban collectors and rural assemblers and the remaining balance was satisfied by their brokers. They played a significant role in price formation at local level, based on price information accessed from exporters; this indicated that they are in good position in accessing price information.

There was no contractual agreement between wholesalers and their suppliers. They had some informal contractual agreements with their buyers when they sell their output to other traders on credit base. The price received by wholesalers was ETB $7.75 / \mathrm{kg}$ (Table 2). Costs incurred by the wholesalers were transportation, loading and offloading, rent of store, sorting, grading, cleaning, and packaging. All wholesalers received credit from commercial bank of Ethiopia and informal sources (friends and relatives). Wholesalers' total gross margin was 24.8, 34.8, 24.8, 24.8, and 24.8 percent of end buyer's price in channel I, II, III, IV and VI respectively (Table 3).

\subsection{Marketing Costs and Margins}

The results of the study on Table 2 revealed that wholesalers incurred relatively higher marketing costs, which was associated with intensive work on cleaning, sorting, grading, and long distance transportation to sell the red beans to the next actors while urban collectors incurred the least marketing cost this low market cost was because they did not work intensively on cleaning, sorting, and grading. The selling price for farmers was different within different marketing channels; the highest selling price was recorded when wholesalers directly bought from farmers. When farmers sold their produce to wholesalers directly, they incurred relatively higher costs because farmers did intensive cleaning and sorting activities whenever they targeted selling their produce to wholesalers and wholesalers did not pay for brokerage, this reduces their marketing costs, hence offered relatively higher price for farmers.

The total gross marketing margin (TGMM) was highest in Channel VI followed by channel III, which accounted for 66.6 percent and 56.2 percent of the end buyer's price, respectively. The result revealed that producer's share in end buyer's price was less than 60 percent in all channels except channels II. The analysis of total gross margins indicated that highest gross margin was accrued by producers in all channels (Table 3 ).

Table 3. Marketing margins of traders for seven market channels and farmers share

\begin{tabular}{|l|l|l|l|l|l|l|l|}
\hline \multirow{2}{*}{ Margins (\%) } & \multicolumn{6}{l|}{ Marketing channels } \\
\cline { 2 - 8 } & I & II & III & IV & V & VI & VII \\
\hline TGMM & 41.07 & 34.84 & 56.17 & 54.45 & 43.29 & 66.59 & 41.82 \\
\hline GMMpco & & & & & & 21.32 & 21.32 \\
\hline GMMcou & & & & & & 20.50 & 20.50 \\
\hline GMMra & & & 24.33 & 29.67 & 43.29 & & \\
\hline GMMuc & 16.30 & & 7.07 & & & & \\
\hline
\end{tabular}




\begin{tabular}{|l|l|l|l|l|l|l|l|}
\hline GMMwh & 24.77 & 34.84 & 24.77 & 24.77 & & 24.77 & \\
\hline GMMp & 58.93 & 65.16 & 43.83 & 45.55 & 56.71 & 33.41 & 58.18 \\
\hline
\end{tabular}

Source: Survey data (2012)

Where, TGMM is total gross marketing margin, GMMpco is gross marketing margin of primary cooperative, GMMcou is gross marketing margin cooperative union, GMMra gross marketing margin of rural assemblers, GMMuc is gross marketing margin of urban collectors, GMMwh is gross marketing margin of wholesalers, GMMp is gross marketing margin of producers (farmers share).

\section{CONCLUSION}

In Halaba Special District, red beans marketing channel needs police formulation and implementing the existing ones on brokers because brokers influenced smallholder red beans producers when they are selling their outputs at market place. Furthermore, the red beans production and marketing should follow modern production and marketing principles with regard to contractual agreement between producers and traders. This calls urgent policy implantation with regard to application of modern marketing principles.

\section{RECOMMENDATION}

There should be a strong emphasis on creating good market networks and linking farmers to reliable markets information. Both government and non-government actors should invest on linking farmers to different information sources to enhance farmers' access to information on marketing channels and associated price. This could be done either by assigning marketing specialists to work at a fee for farmers at the district level or through registering the crop under the Ethiopian Commodity Exchange $(\mathrm{ECX})$ in which market information can be delivered directly from ECX to farmers.

During the survey farmers, urban collectors and rural assemblers complained that brokers were the major challenge in red beans marketing. There is an urgent need for government intervention with regard to Halaba Kulito and Guba market brokers' activities. It is critical to formulate rules and regulations for brokers working along the value chain of red beans in the district. Specifically, red beans farmers are victims of brokers' habits and the District Agricultural and Rural Development and Marketing Departments should work together with red beans farmers to harmonize the operations of brokers along the chain. Furthermore, farmers and traders need training on their record keeping methods to enhance their enterprise management skills.

\section{REFERENCES}

[1] Aysheshm, K, (2007). Sesame market chain analysis: the case of Metema Woreda, North Gondar Zone, Amhara National Regional State. Unpublished M.Sc. thesis, Haramaya University, Ethiopia.

[2] Bindera, J, (2009). Analysis of Haricot bean production, supply, demand, and marketing issues in Ethiopia, Ethiopian Commodity Exchange Authority (ECX), Economic Analysis Team, Addis Ababa, Ethiopia.

[3] Bisschop, A., and Dijk, G. J,(2007). Market Study on Maize and Haricot Beans in Ethiopia. Research Report on Ethiopian Beans.

[4] FAO, (2015). Analysis of price incentives for haricot beans in Ethiopia. Technical notes series by Workao T.K, Masaparisi A, Lanos B, Rome. PP 58.

[5] Ferris, S., and Kaganzi, E, (2008). Evaluating Marketing Opportunities for Haricot beans in Ethiopia. IPMS (Improving Productivity and Market Success) of Ethiopian Farmers Project Working Paper 7. ILRI (International Livestock Research Institute), Nairobi, Kenya.

[6] HSDMD, (2012). Agricultural production and marketing survey in Halaba special district, in Southern Nation and Nationality People Region, Annual Report.

[7] Jagwe, J., N, (2011). The impact of transaction costs on the participation of smallholder farmers and intermediaries in the banana markets of Burundi, Democratic Republic of Congo and Rwanda. PHD dissertation, University of Pretoria, South Africa. 120pp.

[8] Kumar N and Kapoor, (2010) Value chain analysis of coconut in Orissa. Agricultural Economics research review, Volume 23: PP 411-418.

[9] Ketema K.T, (2007). Production and marketing systems of sheep and goats in Alaba, Southern Ethiopia. Unpublished M.Sc. Thesis Hawassa University, Ethiopia. 
[10] LeRoux M, (2010). Guide to marketing channel selection. Agricultural marketing specialist, Cornell Cooperative Extension of Tompkins County, South Central NY Agricultural program.

[11] Mendoza, G, (1995). A Primer on marketing channels and margins. Lyme Rimer Publishers Inc., USA. 425pp.

[12] Mulugeta F, (2010). Profile of Haricot bean production, supply, demand and marketing issues in Ethiopia. Ethiopian Commodity Exchange Authority, PP 50.

[13] Mussema, R, (2006). Analysis of red pepper marketing: the case of Alaba and Silte in SNNPRS of Ethiopia. Unpublished M.Sc. thesis, Haramaya University, Ethiopia.

[14] Mussema, M., and Dawit, A, (2012). Red pepper marketing in Siltie and Alaba in SNNPRS of Ethiopia: factors affecting households' marketed pepper. International Research Journal of Agricultural Science and Soil Science, 2(6):261-266.

[15] Narayanan, S and Bastine, C. L., (2004). Price spread of coconut in the central region of Kerala. Journal of tropical agriculture 42 (1-2): 73-75.

[16] Scott, J., (1995). Price Products, and People Analyzing Agricultural Markets in Developing Countries, Lynne Rinner Publisher and London. 498pp.

[17] Smith, D.L, (1992). Costs, Margins and Returns in Agricultural marketing. Marketing and agribusiness development paper No 1. Marketing and rural finance service (AGSM) agricultural services division food and agriculture organization, Rome.

Citation: A. J. Kabeto, " Major Red Beans Marketing Channels in Halaba Special District, Ethiopia ", International Journal of Research Studies in Agricultural Sciences, vol. 3, no. 12, p. 8-17, 2017. http://dx.doi.org/10.20431/2454-6224.0312002

Copyright: (C) 2017 Authors. This is an open-access article distributed under the terms of the Creative Commons Attribution License, which permits unrestricted use, distribution, and reproduction in any medium, provided the original author and source are credited. 